European plants in a limited area of north-eastern North America; this clearly represents a similar migration in the opposite direction. These species, both in. America and in Ireland, by their very nature could not have migrated across wide stretches of sea. A relatively high land-level may have existed in the late Pliocene, but it must be admitted that the whole matter of these migrations bristles with difficulties.

The flora of Ireland (1100 species of Phanerogams and vascular cryptogams) is only little more than half that of Great Britain. The greater area, range of latitude, and diversity of surface and soil of the latter cannot wholly explain this paucity in flora and fauna of the former. There is little doubt that many of these British species would have invaded Ireland had they been able, but the Irish Sea formed the barrier to western migration, while Britain was still connected by land with the Continent.

There are, too, many interesting, but puzzling cases of discontinuous species in Ireland, occurring only in one or a few bare patches. It is possible that they have been introduced by air from across channel to places unsuited for them. There are, also, certain species more successful in Ireland than in the sister island. The outstanding problems of the Irish flora and fauna are still many and varied, and the study of fossils and of peat can be expected only to reveal part of the story. But research is going on apace.

\title{
Medicine in the Renaissance
}

$\mathrm{T}$ HE Institute of the History of Medicine at Johns Hopkins University in Baltimore, which is the only one of its kind in the United States of America, was the last creation in 1929 of that remarkable and radiant personality, William Henry Welch. "My ambition," he wrote to Dr. L. W. Weed, dean of the Medical School, in a letter dated Novem ber 21,1927 , "is to create a real institute of medical history with a good reference library and a salaried staff, where facilities are offered not only for teaching, but for serious study and research. A 'Lehrstuhl' merely is not enough". The professorship in the history of medicine in the University was originally intended as a retirement chair for Dr. Welch who, however, insisted on the organization of a properly equipped department. $\mathrm{He}$ was succeeded by Dr. Henry E. Sigerist, a former director of the Institut für die Geschichte der Medzin at Leipzig, who, with his magnetic personality, relentless energy, and immense erudition, has built up a magnificent institute serving the triple purpose of research, education, and nucleus for medico-historical activities in the country. Supported by a grant from the Rockefeller Foundation, it is situated on the top floor of the William H. Welch Medical Library. Dr. Sigerist is ably assisted by his associates Drs. Owsei Temkin, Ludwig Edelstein, John Rathbone Oliver, and Sandford V. Larkey. Initially designed as a house-organ, to contain papers written by members of the Institute and by others connected with the University, in January 1933 the Bulletin of the Institute of the History of Medicine began to appear as a supplement to the Jnhns Hopkins Hospital Bulletin, from 1935 functioning as an independent organ. At the beginning of 1939 it changed its name to "Bulletin of the History of Medicine. Organ of the American Association of the History of Medicine and The Johns Hopkins Institute of the History of Medicine".

So successful was the first Graduate Week in Medical History held at the Institute in April 1938 that a similar course was planned for the week of April 24-29, 1939. While last year's programme dealt with the principles and methods of research and teaching, the subject this year was "Medicine in the Renaissance". The course was attended by thirty-nine medical historians and students of the Renaissance, including Prof. Leicester Bradner, of
Brown University; Dr. Iago Galdston, of the New York Academy of Medicine; Prof. Richard H. Shryock, of the University of Pennsylvania; Dr. Kate Campbell-Hurd Mead; Dr. Benjamin Spector ; and Dr. Richmond C. Holcomb. Each morning a lecture, illustrated by an exhibit of the most authoritative literature, and followed by a discussion, was given by Dr. Sigerist and by members of his staff, and the afternoons were devoted to informal round-table seminars. The programme was carefully planned so as to leave sufficient time for individual work and for conversation with the director and his associates.

In the opening lecture on April 24, entitled "Economic, Social, and Political Foundations of the Renaissance", Dr. Sigerist described the medieval world as a static world in which man was born into a definite place and function. Everything was dominated by religion. When the new period started, the system of feudalism began gradually to disintegrate. The struggle between the old and the new orders lasted for three centuries, for feudalism in Western Europe was only overthrown by the French Revolution. The Reformation had enormous economic repercussions : it broke the doctrine of the Church that production is for service only and that the idea of profit is sinful. The fifteenth century witnessed a great development in finance and banking, better and shorter ways of traffic were sought, Western Europe was linked with the New Worlds, and navigation proved a great stimulus to science. Everywhere man felt his individuality, which he desired to apply to a definite purpose. The afternoon's seminar was given up to a discussion of "The Concept of the Renaissance". The term "Renaissance" was first used in art by the sixteenth century Italian art critic and painter Giorgio Vasari. Its technical use dates from Jacob Burckhardt's book "Die Kultur der Renaissance in Italien", 1860. In the evening a play was performed at the Baltimore Museum of Art "The Black Dart of Death", adapted by Dr. Larkey from William Bullein's "A Dialogue against the Fever Pestilence", 1564.

The following day's programme included a lecture by Dr. Edelstein on "Ancient Traditions in Medieval and Renaissance Thought", a seminar on "Bibliographic Problems of Renaissance Literature", and an evening meeting of the Cordell Historical Society of the University of Maryland in the chemical hall 
which had witnessed the bestowing of honorary degrees on Lafayette and Ephraim McDowell. On April 26, Dr. Sigerist spoke on "Science and Technology in the Renaissance", and to the afternoon's seminar on "Some Biological Problems of the Renaissance" Dr. Larkey contributed an account of the anatomical text-books of the period, while Dr. Temkin discussed the anti-Aristotelian movement. On April 27, Dr. Temkin, lecturing on "The Physician in the Renaissance", attributed the esteem in which he was held not to his efficiency (in contemporary satires he is more freely attacked than the surgeon), but rather to the academic and financial difficulties attending the acquisition of the M.D. in the sixteenth century. Bearing in mind that the average lifetime of a man in those days was not more than fifty years, at the end of his training the young doctor had already spent more than half his life in study. The medieval physician was restricted in his interests, all scientific knowledge being centred in the philosophers and the theologians. With the Renaissance, the physician began to enter the field of mathematics, mineralogy, chemistry, zoology, and literature. The afternoon's seminar dealt with "Diseases prevailing in the Renaissance and their Interpretation". On
April 28, Dr. Larkey spoke on "Hygiene and Public Health in the Renaissance", the subject of the afternoon's discussion being "Medical Literature in the Vernacular : English, German, French, Italian". The closing address of the course was delivered by Dr. Alan M. Chesney, dean of the Medical School, who dealt with the early history of the Johns Hopkins Hospital, the fiftieth birthday of which is commemorated this month.

The intellectual fare of the Graduate Week was temptingly seasoned with tea and cocktail parties, dinners and visits to shrines of interest, such as the Tudor and Stuart Club of Johns Hopkins University, with which the name of Revere Osler, Sir William's only son, is inseparably linked.

The following exhibits had been arranged: Leonardo da Vinci ; medical books from the Renaissance presses; and recently published literature in medical history.

At the banquet on April 28, Dr. John Rathbone Oliver spoke on "The Oxford of Anthony Wood", and a presentation was made to Dr. Sigerist and to the very efficient and charming machine behind his brain--his secretarial staff.

WALTER BETT.

\section{Soil Mechanics}

$\mathrm{P}$ ROF. KARL VON TERZAGHI delivered the forty-fifth James Forrest Lecture at the Institution of Civil Engineers on May 2, taking as his subject "Soil Mechanies: a New Chapter in Engineering Science".

At the opening of his address, Dr. von Terzaghi contrasted the empirical methods which were in general use until about twenty-five years ago with the much greater reliability which is now obtainable by allowing for the effects of soil movements and pressures. So unsatisfactory to progressive engineers had the old procedure become of ascertaining the bearing capacity of subsoil that concerted action was taken to study the properties and behaviour of soil and to place these on a sound basis in accordance with the laws of mechanics. The new study was designated 'soil mechanies', a name which in 1936 received confirmation when the first International Conference on Soil Mechanics and Foundation Engineering was held at Harvard University in Cambridge, Massachusetts.

Dealing with the first section of his subject, "The Pressure of Earth on Lateral Supports", Dr. von Terzaghi showed that Coulomb's theory, which is the more reliable of the two in use and dates from 1773 , was based on several untenable assumptions. The modifications made in the formulæ as now used have arisen from the discovery that the intensity and distribution of earth pressure depend on many more factors than were realized by earlier workers. Dr. von Terzaghi indicated the nature of, and justification for, these modifications.

Passing to the closely related problem of earth pressures involved in the stability of slopes, Dr. Terzaghi showed that the old method was to prescribe that slopes of fills and cuts should be established at angles somewhat smaller than the appropriate angles of repose. Mention was made of what is known as the Swedish method of determining the degree of stability of a slope, which is based on the empirical fact that the profile of the surface of sliding always approaches the form of a circular arc. For masses of earth having little cohesion and subjected to seepage forces, as in the case of an embankment for water storage, the formulæ adduced in recent studies were shown to give satisfactory results. In the case of clays, however, the determination of the shearing resistance is far more difficult and the position at present is still highly controversial.

A submerged body of soil with little cohesion and in a loose state is liable on the least disturbance to behave as a liquid and to flow on a horizontal surface, a phenomenon which is known as 'flow-slide'. Here the condition was shown to be that the material should be loose enough to be capable of reducing to a denser state as a result of the applied deformation. Flow-slide was thus shown to be associated with porosity, and no flow failure can occur unless the volume at this occurrence is less than the initial volume. The necessity, therefore, of specifying that the porosity of water-retaining embankments should be well below the critical value was thus made clear.

The compaction of embankments is an effective means of limiting the amount of settlement, as in the case of fills for road making, and R. R. Proctor has demonstrated that the degree of compaction produced by a given method depends on the moisture content, being greatest for a certain medium watercontent, determinable by experiment. These observations have led to fill-construction methods in which moisture-content controls are introduced. In Germany, the compaction of sandy soil by vibration has been brought to a high state of perfection, and it has been found that the greatest compacting effect is 